\title{
EFFECT OF WETTING-DRYING CYCLES ON VOLUMETRIC STABILITY OF CLAYEY SOIL STABILIZED WITH LIME AND PERLITE
}

\author{
Fatih YILMAZ *1, Duygu FIDAN ${ }^{2}$ \\ ${ }^{1}$ Engineering Faculty/Institute of Natural Sciences/Bayburt University \\ ${ }^{2}$ Engineering Faculty/Institute of Natural Sciences/Bayburt University \\ *Corresponding author; fyilmaz@bayburt.edu.tr
}

In this study, which is about the stabilization of the clayey soils, natural soil is mixed with $6 \%$ lime (optimum lime ratio) and 0\%, 5\%, 10\%, 15\%, 20\%, 25\%, 30\% perlite. Perlite was used in this study in natural and fine grained form, separately. The test specimens prepared for the wetting-drying period were cured in the desiccator for 28 days. After curing, the test specimens were subjected to 12 wettingdrying periods according to ASTM D 559. In this study based on volumetric stability, it was observed that the natural soil sample could not maintain its volumetric integrity on the $2^{\text {nd }}$ day and dispersed. According to the durability conditions required in lime, cement, pozzolana-lime and pozzolana-cementlime mixtures, the maximum allowable loss in sample weight at the end of 12 wetting-drying periods is between 6-14\%. As a result of this study, it was seen that SLP2 samples were found to provide durability conditions against 12 wetting-drying periods.

Key words: soil stabilization, wetting-drying period, lime, perlite, fineness effect

\section{Introduction}

Stabilization of soil in geotechnical engineering means the increase in soil engineering properties. Expansive soils, which have high clay contents, are problematic soils that need to be stabilized. The volume changes of expansive soils is damager when subjected to moisture insconstancy [1]. Expansive soils can lead to foundation problems, distortions and failures in structures due to their shrinkage and swelling behavior [2]. Engineering properties and bearing capacity of expansive clayey soils is low. On the other hand, high settlement of expansive soil is detrimental for structures and geotechnical projects [3]. Therefore, amendment of expansive soils is necessary to diminish their destructive effects [4].

Lime can be used as an additive material for the stabilization of soft expansive clayey soils. Literature studies indicate that lime stabilization studies are frequently carried out [5-23]. In recent studies, pozzolanic additives have begun to be used besides the usage of lime [23-28]. Pozzolans are materials which, at normal temperature values, may have binding properties in the presence of water and especially in combination with lime [29]. Compounds formed as a result of chemical reaction with lime exhibit a water-insoluble stability [30].

In this stabilization study, perlite was used as a pozzolanic additive. According to Erdem et. al. 2007 [31], perlite reserves of the world is around 6700 millions tons. There are abundant perlite reserves in Nevsehir, Ankara and Erzincan region in Turkey [32]. The perlite formations in Turkey are close to the surface. Therefore, there is no difficulty for the production of it [33].

The effects on the wetting-drying cycle of using fine grained or natural perlite and lime in soil stabilization has not been widely studied. The main purpose of this study was to examen the use of 
natural pozzolanic perlite with lime in soil stabilization, and the effect of grinding of perlite on the durability tests based on volumetric stability.

\section{Materials and Methods}

Soil was taken from a fine-grained soil deposit of Demirözü-Bayburt. The classification of the soil is 'low plasticity clay (CL)' according to the Unified Soil Classification System. Fig. 1 shows grain size distribution curve of the soil. Index properties of the expansive soil are summarized in Tab. 1.

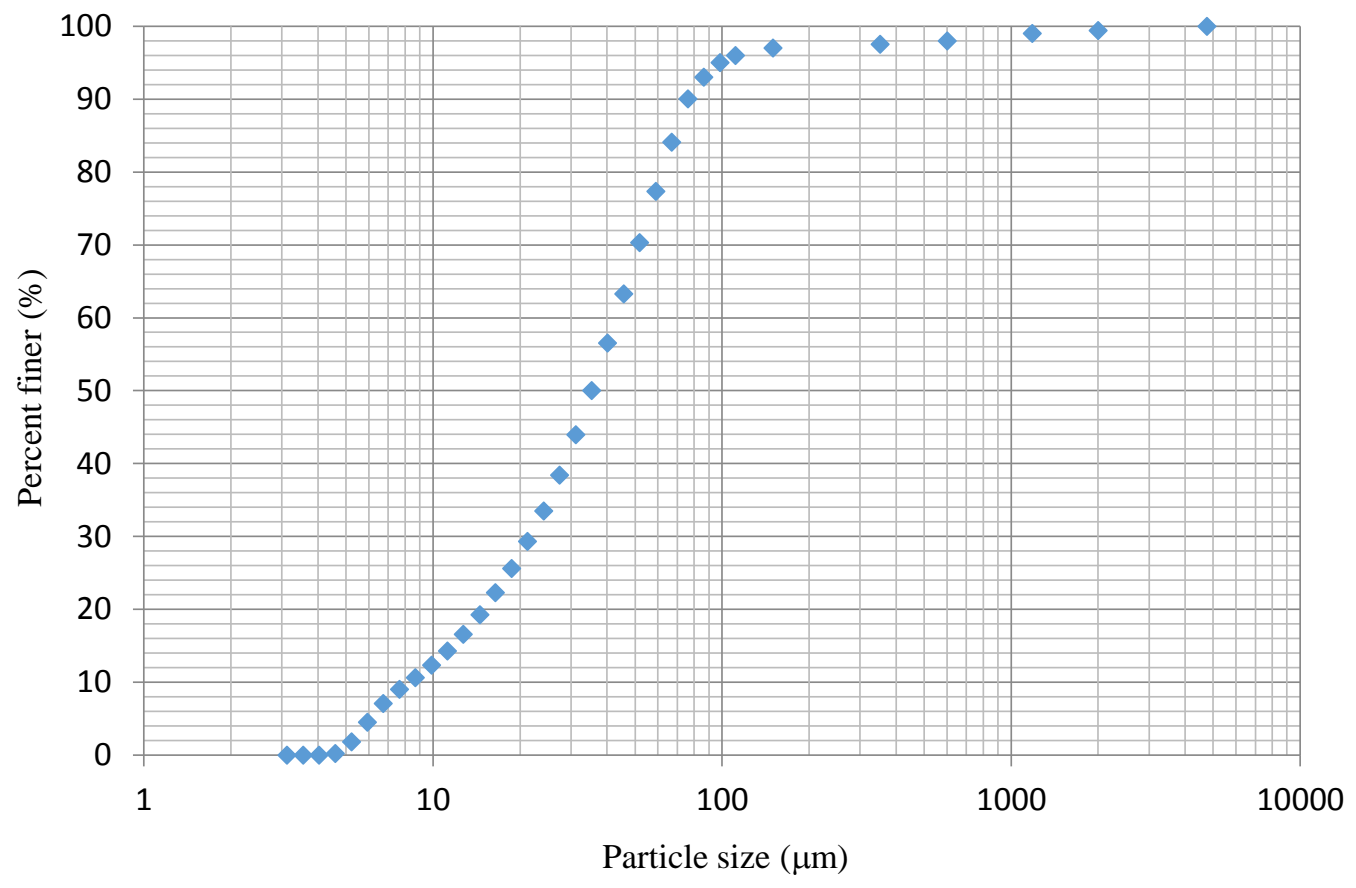

Fig. 1 Grain size distribution curve of clay soil

Table 1 Index properties of the expansive soil

\begin{tabular}{cc}
\hline Property & Value \\
\hline USCS classification & $\mathrm{CL}$ \\
Liquid limit, LL (\%) & 48,8 \\
Plastic limit, PL (\%) & 26,5 \\
Plasticity index, PI (\%) & 22,3 \\
Specific gravity & 2,60 \\
Optimum water content, $\mathrm{w}_{\mathrm{opt}}(\%)$ & 23,0 \\
Maximum dry density, $\rho_{\mathrm{kmax}}\left(\mathrm{Mg} / \mathrm{m}^{3}\right)$ & 1,63 \\
Color & Flavescent \\
\hline
\end{tabular}

Minerals of expansive clay soil is identified by X-ray diffraction. Analysis results of X-ray diffraction are given in Fig. 2. The main mineralogical portion of the soil are quartz and calcite.

Chemical properties of the lime are shown in Tab. 2. And The grain size distribution curve of the lime is given in Fig. 3. 


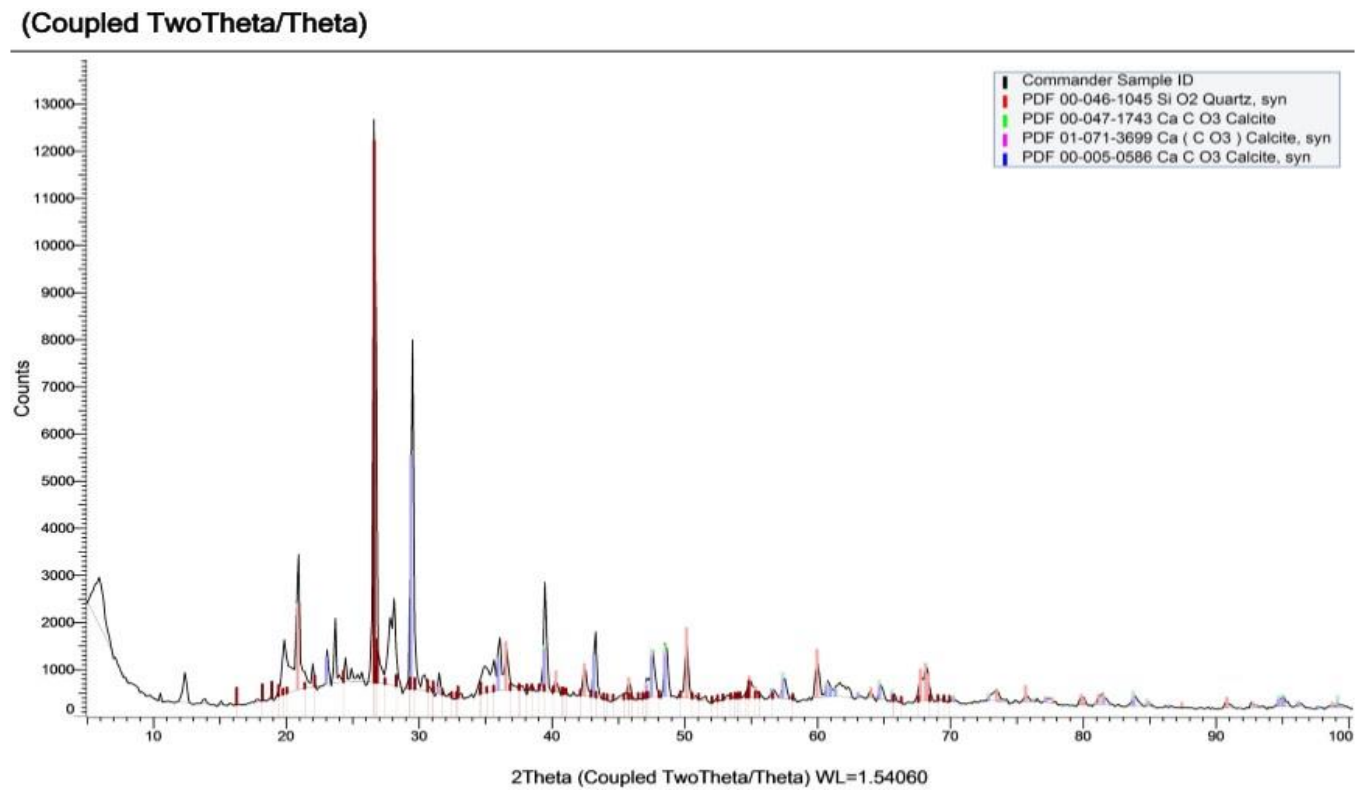

Fig. 2 X-ray diffraction of expansive soil

Table 2 Lime properties

\begin{tabular}{cc}
\hline Property & Value \\
\hline $\mathrm{Ca}(\mathrm{OH})_{2}(\%)$ & 85.80 \\
$\mathrm{Active} \mathrm{CaO}(\%)$ & 65.00 \\
$\mathrm{MgO}(\%)$ & 1.40 \\
$\mathrm{SiO}_{2}(\%)$ & 0.23 \\
$\mathrm{Al}_{2} \mathrm{O}_{3}(\%)$ & 0.11 \\
$\mathrm{Fe}_{2} \mathrm{O}_{3}(\%)$ & 0.40 \\
Density $\left(\mathrm{Mg} / \mathrm{m}^{3}\right)$ & 0.48 \\
Grain specific gravity $\left(\mathrm{Mg} / \mathrm{m}^{3}\right)$ & 2.37 \\
$\mathrm{pH}$ value & 12.4 \\
$>75-\mu \mathrm{m}(\%)$ & 3.8 \\
\hline
\end{tabular}

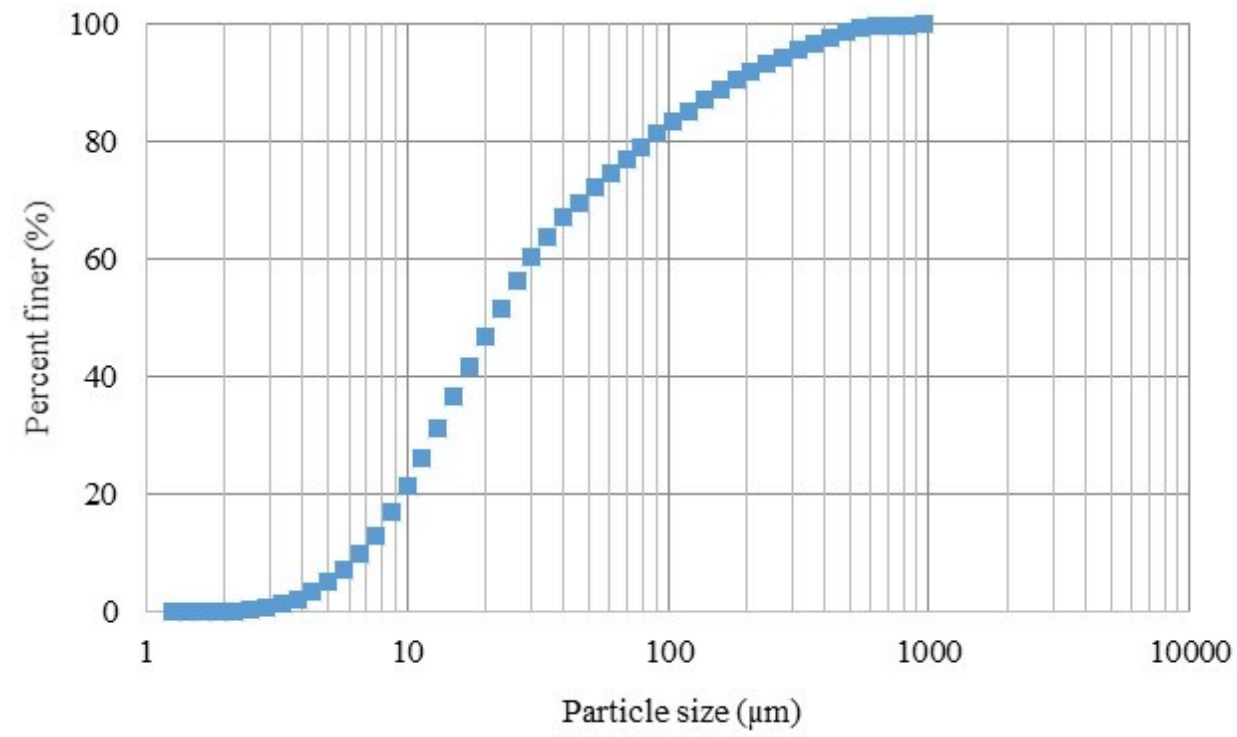

Fig. 3 Grain size distribution curve of hydrated lime 
Perlite was taken from in Mollaköy-Erzincan, Turkey. Engineering properties of the perlite are summarized in Tab. 3. Fig. 4 shows X-ray diffraction test results of the perlite. The fine grained perlite was passed through a $0.075 \mathrm{~mm}$ sieve aperture. The grain size distribution curve of natural and fine grained form of the perlite is shown in Fig. 5.

Table 3 Physical and chemical properties of the perlite

\begin{tabular}{cc}
\hline Property & Value \\
\hline Specific gravity & 2,24 \\
Fineness (\%) (passing $45 \mu \mathrm{m})$ & 10.2 \\
$\mathrm{pH}$ & 6.5 \\
Specific surface area $\left(\mathrm{cm}^{2} / \mathrm{g}\right)$ & 3515 \\
Atterberg limits & $\mathrm{NP}$ \\
Optimum water content, $\mathrm{w}_{\text {opt }}(\%)$ & 2.04 \\
Maximum dry density, $\rho_{\mathrm{kmax}}\left(\mathrm{Mg} / \mathrm{m}^{3}\right)$ & 1,56 \\
Color & $\mathrm{Gray}$ \\
USCS classification & $\mathrm{SW}-\mathrm{SM}$ \\
\hline Chemical composition $(\%)$ & \\
\hline Silica $\left(\mathrm{SiO}_{2}\right)$ & 69.21 \\
Alumina $\left(\mathrm{Al}_{2} \mathrm{O}_{3}\right)$ & 11.94 \\
Iron oxide $\left(\mathrm{Fe}_{2} \mathrm{O}_{3}\right)$ & 1.34 \\
Calcium oxide $(\mathrm{CaO})$ & 2.36 \\
Potash $\left(\mathrm{K}_{2} \mathrm{O}\right)$ & 2.78 \\
Magnesia $(\mathrm{MgO})$ & 0.94 \\
$\mathrm{Na}_{2} \mathrm{O}$ & 5.42 \\
$\mathrm{SO}_{3}$ & 0.06 \\
Loss of ignition & 4.16 \\
\hline
\end{tabular}

\section{(Coupled TwoTheta/Theta)}

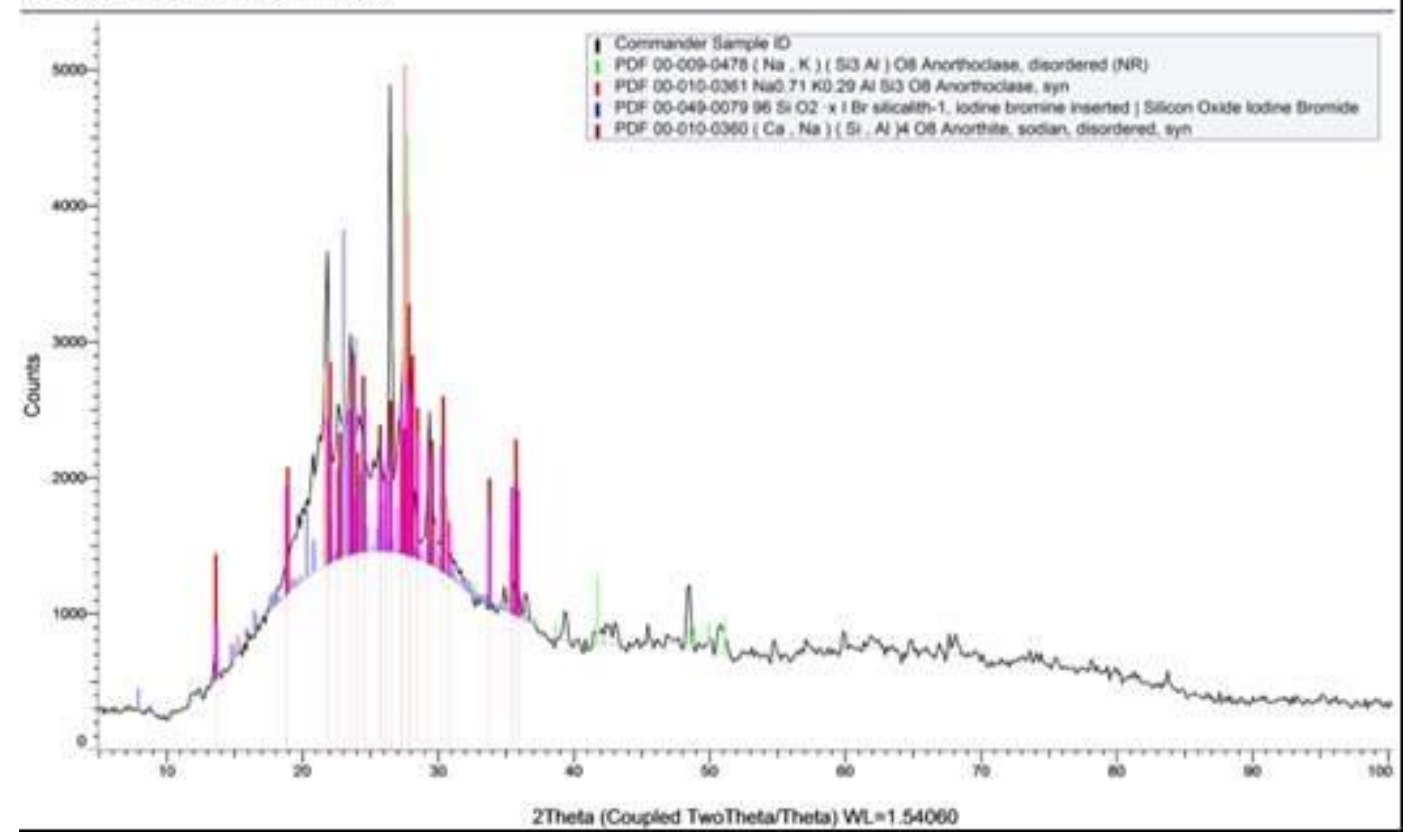

Fig. 4 X-ray diffraction of the perlite 


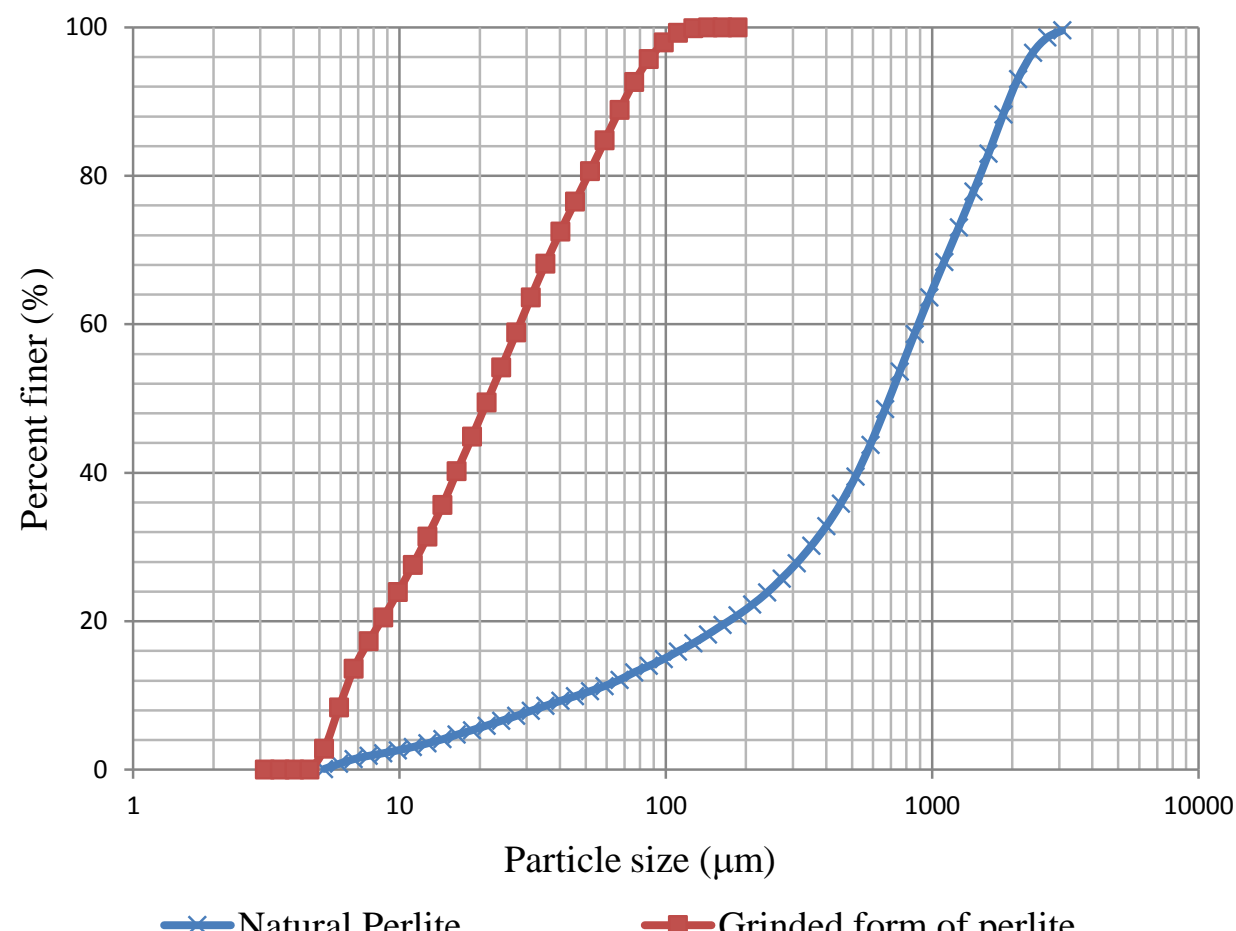

Fig. 5 Grain size distribution curve of perlite

Table 4 Notation of specimens

\begin{tabular}{ll}
\hline Mixing ratios of test specimens & Notation \\
\hline Natural soil & S \\
Natural soil and lime & SL \\
Soil, lime and perlite & SLP \\
\hline Soil, lime and \%5 perlite (1. Group) & SLP1/5 \\
\hline Soil, lime and \%10 perlite (1. Group) & SLP1/10 \\
\hline Soil, lime and \%15 perlite (1. Group) & SLP1/15 \\
\hline Soil, lime and \%20 perlite (1. Group) & SLP1/20 \\
\hline Soil, lime and \%25 perlite (1. Group) & SLP1/25 \\
\hline Soil, lime and \%30 perlite (1. Group) & SLP1/30 \\
\hline Soil, lime and \%5 perlite (2. Group) & SLP2/5 \\
\hline Soil, lime and \%10 perlite (2. Group) & SLP2/10 \\
\hline Soil, lime and \%15 perlite (2. Group) & SLP2/15 \\
\hline Soil, lime and \%20 perlite (2. Group) & SLP2/20 \\
\hline Soil, lime and \%25 perlite (2. Group) & SLP2/25 \\
\hline Soil, lime and \%30 perlite (2. Group) & SLP2/30 \\
\hline
\end{tabular}

The notations of the samples prepared within the scope of the study are presented in Tab. 4. SLP1 specimens were prepared with using natural perlite and fine grained perlite was used for the preparation of SLP2 specimens.

\section{Results and Discussions}

In order to determine the optimum lime ratio, the $\mathrm{pH}$ of the natural soil (S) was appropriately tested according to ASTM D 6276 [34]. HANNA 2211 pH/ORP Meter device was used in the experiment. The $\mathrm{pH}$ values for the solutions prepared to determine the optimum lime ratio are given in 
Tab. 5. When the relevant data are examined, it was seen that the $5 \%$ of solution provides optimum lime ratio conditions. However, literature studies [35,36] have figured out that, the amount of lime ratio should exceed this value if an increase of strength needed in soil stabilization. In the light of literature investigations, the optimum lime ratio in this study was set at $6 \%$.

Table $5 \mathrm{pH}$ test results

\begin{tabular}{ll}
\hline Lime ratio & pH value \\
\hline$\% 0$ & 9.8 \\
$\% 1$ & 11.3 \\
$\% 2$ & 12.2 \\
$\% 3$ & 12.3 \\
$\% 4$ & 12.4 \\
$\% 5$ & 12.6 \\
$\% 6$ & 12.6 \\
$\% 7$ & 12.6 \\
$\% 8$ & 12.6 \\
$\% 10$ & 12.6 \\
\hline
\end{tabular}

The liquid limit (LL), plastic limit (PL) and plasticity index (PI) values of the samples are given in Fig. 6. These experiments were carried out in accordance with ASTM D 4318 [37].

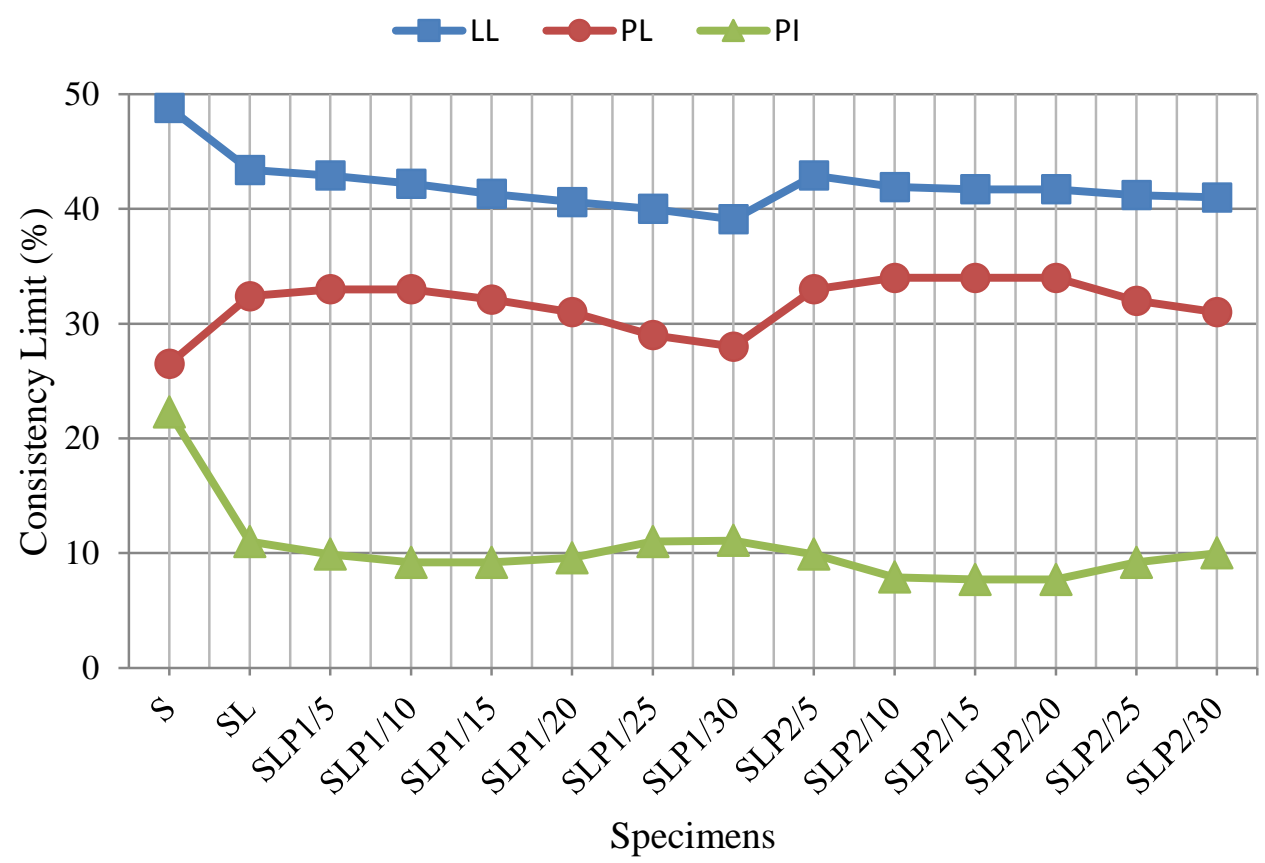

Fig. 6 Atterberg limits

The consistency limits were made immediately after the specimens were prepared. It is seen that the liquid limit and plasticity index values of the natural soil sample are higher than all the additive mixtures. The liquid limit values of the SLP specimens are less than the liquid limit value of the SL specimen. The liquid limit values of the SLP1 and SLP2 mixtures decreased with the increasing of the perlite rate. SLP1 mixtures were found to have lower liquid limit values than SLP2 mixtures. The lowest 
value of the liquid limit was determined from SLP1/30 specimen. An increase in the plastic limit value was observed for the SL mixture according to the poor soil sample. The plasticity index value of the SLP mixturex decreased according to $S$ specimen.

Compaction tests were carried out in accordance with ASTM D 698 [38]. Graphs of optimum water content and maximum dry density of the SLP1 and SLP2 specimens are given in Fig 7 and 8, separately. As it can be seen from Fig. 7, the optimum water content was increased with respect to the natural soil in the SL specimen, while the maximum dry density decreased. The maximum dry density values of the SLP1 mixtures increased with respect to the SL mixture, while the optimum water content values decreased. The maximum dry density values increased as the perlite ratio in SLP1 mixtures increased. One can understand from Fig. 8, the maximum dry density values of the SLP2 mixtures increased with respect to the SL mixture, while the optimum water content values decreased. The maximum dry density values increased as the perlite ratio in SLP2 mixtures increased.

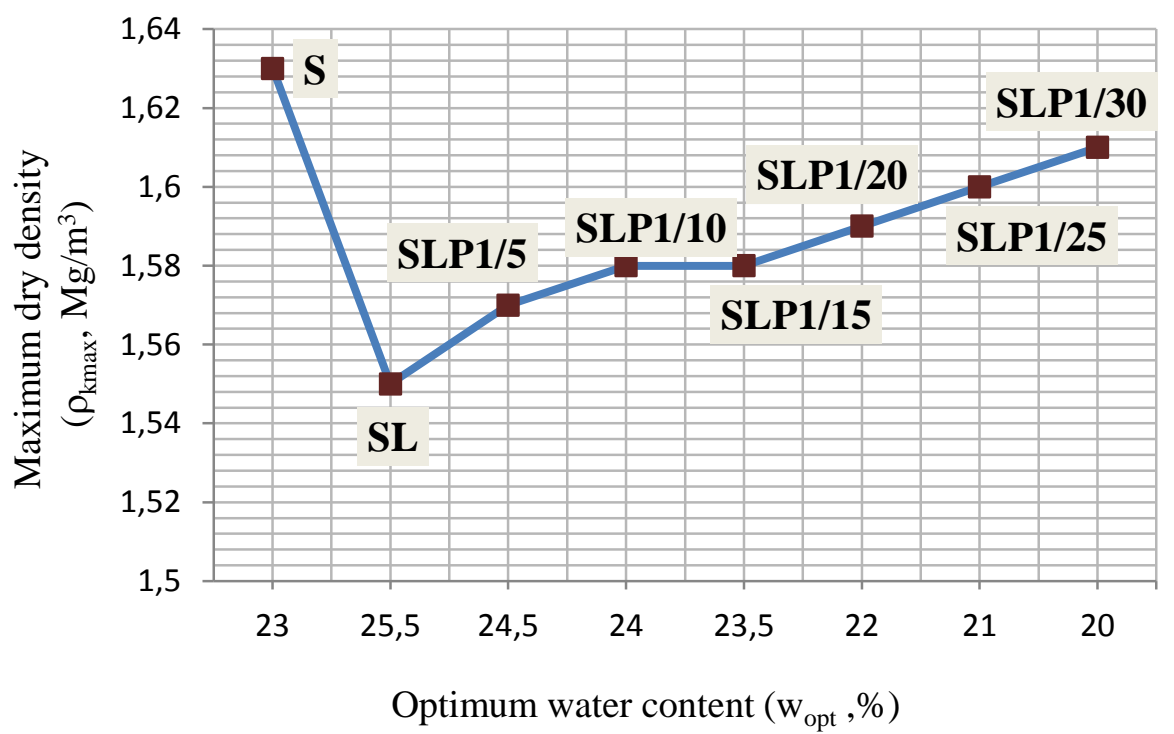

Fig. 7 Compaction parameters of SLP1 specimens

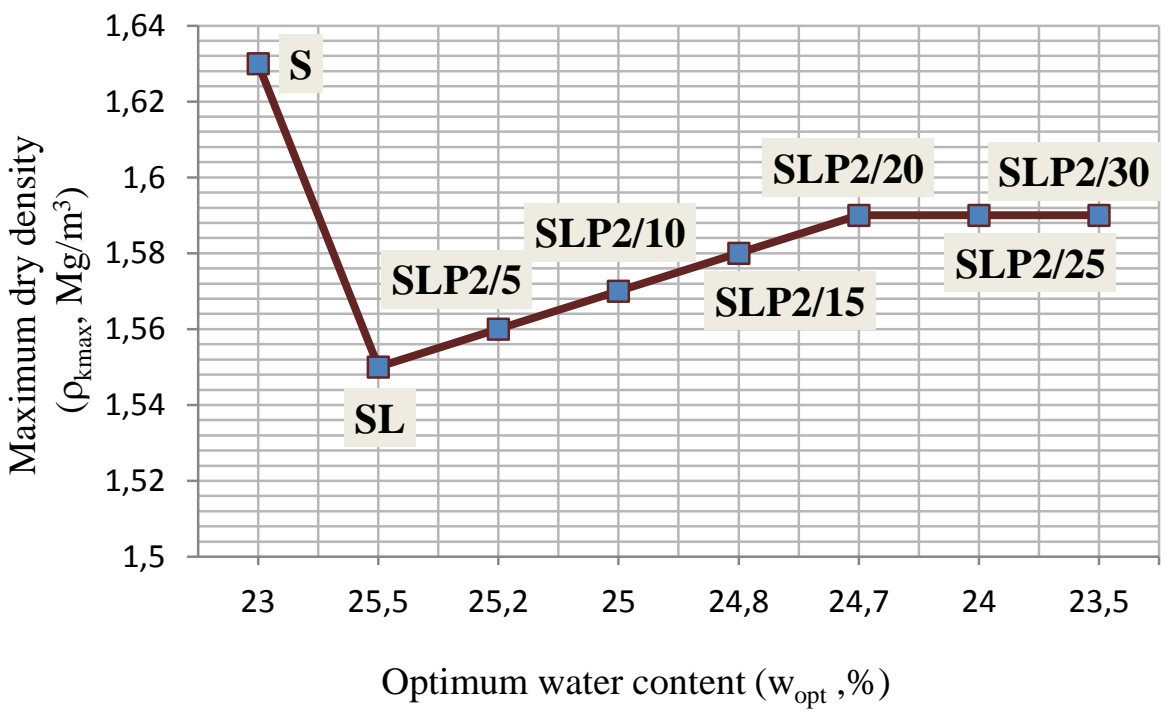

Fig. 8 Compaction parameters of SLP2 specimens 
The durability requirements of the additive samples of the clayey soils should be $6-14 \%$ as the maximum allowable loss of the sample weight at the end of the 12 weting-drying periods. Based on these durability criteria, the behavior of the samples in the wetting-drying period test was investigated. The test specimens prepared for the wetting-drying period were first cured in the desiccator for 28 days. After the curing process, the test samples were subjected to 12 wet-drying cycles according to ASTM D 559 [39]. Fig. 9 represents wetting-drying cycle of test specimens.
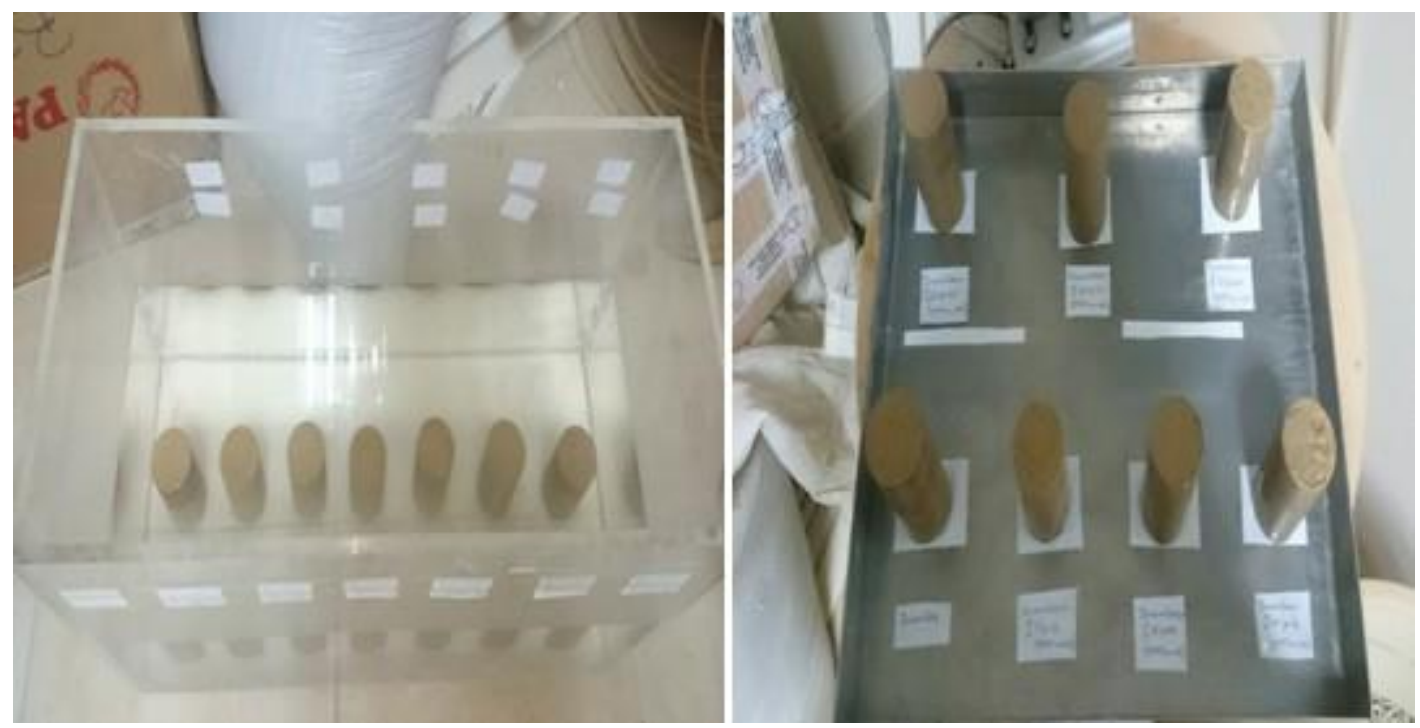

Fig 9. Wetting-drying period of specimens

The S specimen was not able to maintain its volumetric stability on the 2nd day of wetting-drying period. The weight loss curve for the wetting-drying period of the SL and SLP1 specimens is given in Fig 10. The weight loss curve in the wetting-drying period of SL and SLP2 mixtures is shown in Fig 11.

Wetting-drying period

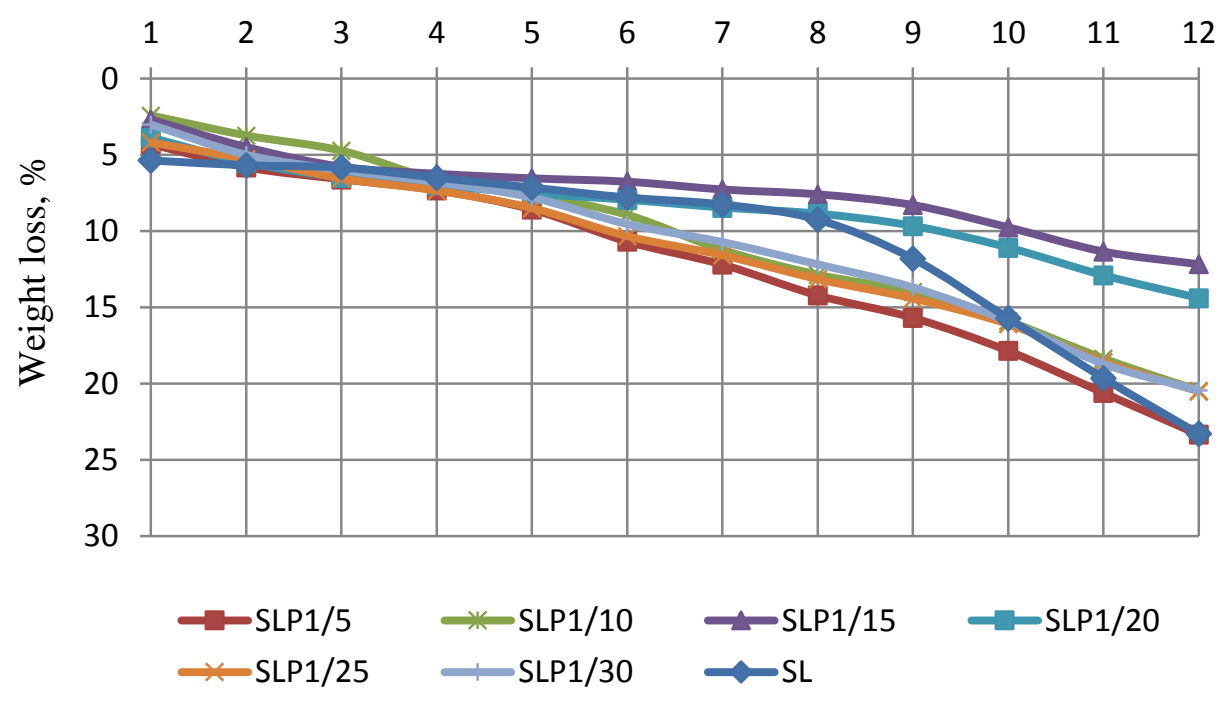

Fig 10. Weight loss curve of SLP1 specimens 
Wetting-drying period

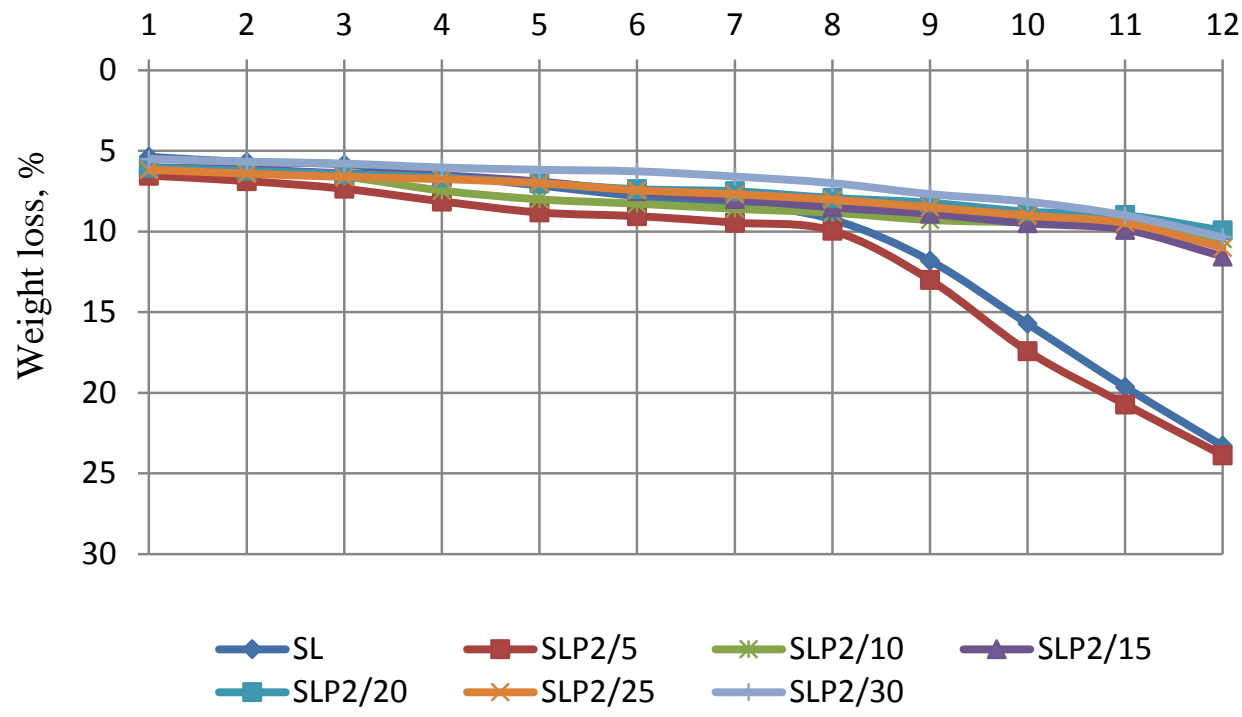

Fig 11. Weight loss curve of SLP2 specimens

As a result of wetting-drying periods of SPL1 specimens it was seen that, SL, SLP1/10, SLP1/25, SLP1/30 specimens were durable at the end of the 9 wetting-drying cycles, but the volumetric stability these specimens began to deteriorate at later periods. The volumetric stability of SLP1/5 specimens began to weaken after 8 wetting-drying periods, SLP1/15 and SLP1/20 specimens fulfilled durability conditions against the wetting-drying period 12 times. Although SLP2/5 specimen meets the durability criteria at the end of the wetting-drying period 9 times, the weight loss is observed at the end of the 12 wetting-drying. SLP2/10, SLP2/15, SLP2 /20, SLP2/25 and SLP2/30 provided durability criteria by maintaining the volumetric integrity after 12 times of wetting-drying period. For SL, SLP1 and SLP2 specimens, the conditions after 12 wetting-drying cycles are given in Fig 12 and Fig. 13., separately.

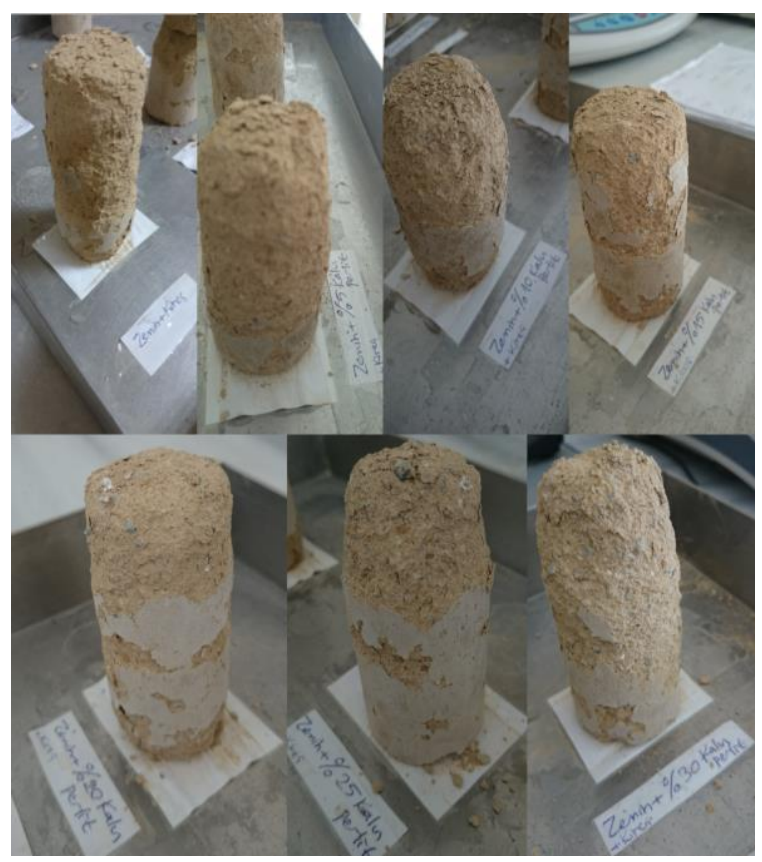

Fig 12. SLP1 wetting-drying specimens 


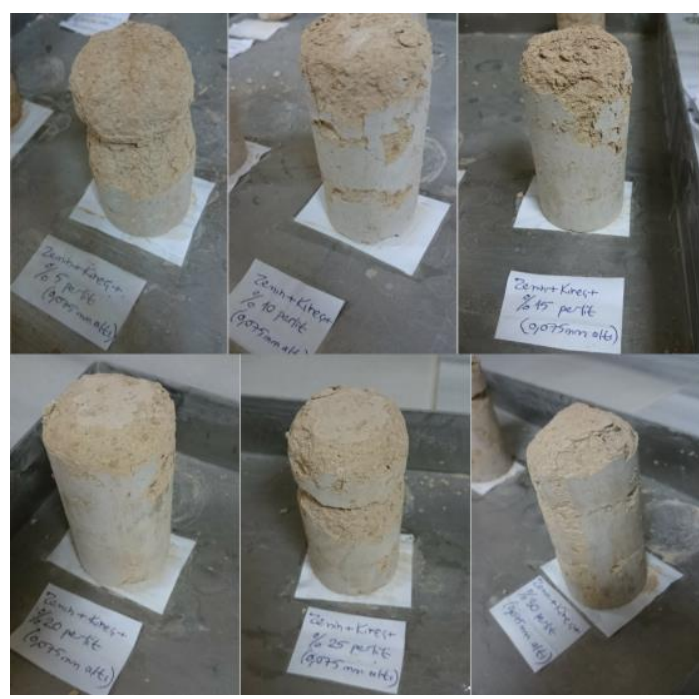

Fig 13. SLP2 wetting-drying specimens

\section{Conclusion}

The major objective of this study was to investigate fineness effect of perlite in soil stabilization under wetting-drying conditions. For this purpose, test specimens with a diameter of $50 \mathrm{~mm}$ and a height of $100 \mathrm{~mm}$ were exposed to 12 times of wetting-drying period in the scope of this study. Part of the aim of this study was to examine optimum lime ratio of test specimens. As a result of the $\mathrm{pH}$ tests carried out for the determination of the lime ratio, the optimum lime ratio of the soil was determined as $6 \%$ and the mixtures were prepared taking this ratio into consideration.

Test specimens were cured 28 days and exposed to wetting-drying period. It was found that $\mathrm{S}$ and SL mixture samples did not maintain volumetric stability. The natural soil completely lost its volumetric stability on the $2^{\text {nd }}$ day of wetting-drying period. In contrast, SL samples retained their volumetric stability for 8 period. Beside this, it was seen that the results of SLP1 mixtures is not effective. As a result of SLP1 specimens, only SLP1/15 and SLP1/20 specimens fulfilled durability conditions against 12 wetting-drying period. Generally, other SLP1 specimens have showed durability up to the end of the 9 wetting-drying cycle. SLP2 samples have showed more resistance against 12 wetting-drying period. SLP2/10, SLP2/15, SLP2/20, SLP2/25 and SLP2/30 mixtures retained the volumetric stability after 12 times wetting-drying period. These differences on wetting-drying behavior of SLP1 and SLP2 specimens can be explained by means of perlite fineness effect. That the SLP2 specimens have greater volumetric stability than the SLP1 specimens is a clear indication of the fineness effect. The results obtained in the study have shown that, using fine grained pozzolanic additives in soil stabilization studies is more efficient than using in natural form.

\section{References}

[1] Khemissa, M. and Mahamedi, A., Cement and Lime Mixture Stabilization of an Expansive Overconsolidated Clay, Applied Clay Science, 95 (2014), pp. 104-110.

[2] Phanikumar, B. R. and Singla, R., Swell-Consolidation Characteristics of Fibre-Reinforced Expansive Soils, Soils and Foundation, 56 (2016), pp. 138-143.

[3] Goodarzi, A. R., Akbari, H. R. et. al., Enhanced Stabilization of Highly Expansive Clays by Mixing Cement and Silica Fume, Applied Clay Science, 132 (2016), pp. 675-684. 
[4] Yilmaz, F. and Yurdakul, M., Evaluation of Marble Dust for Soil Stabilization, Acta Physica Polonica A, 132 (2017), pp. 710-711.

[5]Clare, K. E. and Crunchley, A. E., Laboratory Experiments in the Stabilization of Clays with Hydrated Lime, Geotechnique, 5 (1957), pp. 97-111.

[6] Bell, F. G., Lime Stabilization of Clay Minerals and Soils, Engineering Geology, 42 (1996), pp. 223 237.

[7] Akawwi, E. and Al-Kharabsheh, A., Lime Stabilization Effects on Geotechnical Properties of Expansive Soils in Amman-Jordan, Electronic Journal of Geotechnical Engineering, 5 (2000), pp. 110.

[8] Rajasekaran, G. and Rao, S. N., Permeability Characteristics of Lime Treated Marine Clay, Ocean Engineering, 29 (2002), pp. 113-127.

[9] Tonoz, M.C., Ulusay, R. et. al., Effect of Lime Stabilization on Engineering Properties of Expansive Ankara Clay, Earth and Environmental Science, 104 (2004), pp. 466-474.

[10] Sivapullaiah, P.V. and Lakshmikantha, H., Lime Stabilized Illite as a Liner, Ground Improvement, 9 (2005), pp. 39-45.

[11] Arabani, M. and Karami, M.V., Geotechnical Properties of Lime Stabilized Clayey Sands, The Arabian Journal of Science and Engineering, 32 (2007), pp. 11-25.

[12] Manasseh, J. and Olufemi, A. I., Effect of Lime on Some Geotechnical Properties of Igumale Shale, Electronic Journal of Geotechnical Engineering, 13 (2008), pp. 1-12.

[13] Sakr, M. A. and Shahin, M. A., Utilization of Lime for Stabilizing Soft Clay Soil of High Organic Content, Geotechnical Geological Engineering, 27 (2009), pp. 105-113.

[14] Al-Mukhtar, M., Khattab, S. et. al., Microstructure and Geotechnical Properties of Lime-Treated Expansive Clayey Soil, Engineering Geology, 139 (2012), pp. 17-27.

[15] Al-Mukhtar, M., Lasledj, A. et. al., Behaviour and Mineralogy Changes in Lime-Treated Expansive Soil at 50 C, Applied Clay Science, 50 (2010), pp. 199-203.

[16] Bozbey, I. and Garaisayev, S., Effects of Soil Pulverization Quality on Lime Stabilization of an Expansive Clay, Environmental Earth Science, 60 (2010), pp. 1137-1151.

[17] Cuisinier, O., Auriol, J. C. et. al., Microstructure and Hydraulic Conductivity of a Compacted LimeTreated Soil, Engineering Geology, 123 (2011), pp. 187-193.

[18] Miqueleiz, L., Ramírez, F. et. al., The Use of Stabilised Spanish Clay Soil for Sustainable Construction Materials, Engineering Geology, 133 (2012), pp. 9-15.

[19] Zukri, A., Pekan Soft Clay Treated with Hydrated Lime as a Method of Soil Stabilizer, Procedia Engineering, 53 (2013), pp. 37-41.

[20] Ciancio, D., Beckett, C. T. S. et. al., Optimum Lime Content Identification for Lime-Stabilised Rammed Earth, Construction and Building Materials, 53 (2014), pp. 59-65.

[21] Sante, M. D., Fratalocchi, E. et. al., Time of Reactions in a Lime Treated Clayey Soil and Influence of Curing Conditions on its Microstructure and Behaviour, Applied Clay Science, 99 (2014), pp. 100109

[22] Akcanca, F. and Aytekin, M., Impact of Wetting-Drying Cycles on the Hydraulic Conductivity of Liners Made of Lime-Stabilized Sand-Bentonite Mixtures for Sanitary Landfills, Environmental Earth Science, 72 (2014), pp. 59-66.

[23] Onal, O., Lime Stabilization of Soils Underlying a Salt Evaporation Pond: A Laboratory Study, Marine Georesources\&Geotechnology, 33 (2015), pp. 391-402. 
[24] Jha, J. N. and Gill, K. S., Effect of Rice Hush Ash on Lime Stabilization, Journal of the Institution of Engineers, 87 (2006), pp. 33-39.

[25] Olgun, M., The Effects and Optimization of Additives for Expansive Clays under Freeze-Thaw Conditions, Cold Reg. Sci. Technol., 93 (2013), pp. 36-46.

[26] Calik, U. and Sadoglu, E., Engineering Properties of Expansive Clayey Soil Stabilized with Lime and Perlite, Geomechanics and Engineering, 6 (2014), pp. 403-418.

[27] Yilmaz, F., Kamiloglu, H. A. et. al., Soil Stabilization with Using Waste Materials Against Freezing Thawing Effect, Acta Physica Polonica A, 128 (2015), pp. 392-394.

[28] Fidan, D., Fineness effect of natural pozzolanic additive on strength and durability in stabilization of clays, MSc. Thesis, Bayburt University, Bayburt, Turkey, 2016.

[29] Yilmaz, F., Investigation Usage of Tuffite Stone with Lime in Soil Stabilization by Standard Tests and Computed Tomography Method, Ph. D. thesis, Karadeniz Technical University, Trabzon, Turkey, 2015.

[30] Massazza, F., Pozzolanic Cements and Usage Fields, Turkish Cement Manufacturers' Association, Ankara, Turkey, 1989.

[31] Erdem, T. K., Meral, Ç., et. al., Use of Perlite as a Pozzolanic Addition in Producing Blended Cements, Cement and Concrete Composites, 29 (2007), pp. 13-21.

[32] General Directorate Of Mineral Research And Explorations, http://www.mta.gov.tr

[33] Çalık, Ü., Utilization of Perlite as a Pozzolanic Additive in Soil Stabilization with Lime, Ph. D. thesis, Karadeniz Technical University, Trabzon, Turkey, 2012.

[34] ASTM D 6276, Standard Test Method for Using pH to Estimate the Soil-Lime Proportion Requirement for Soil Stabilization, West Conshohocken, PA, USA, 2015.

[35] Mathew, P. K. and Rao, S. N., Effect of Lime on Cation Exchange Capacity of Marine Clay, Journal of Geotechnical and Geoenvironmental Engineering, 123 (1997), pp. 183-185.

[36] Al-Rawas, A. A., Taha, R., et. al., A Comparative Evalution of Various Additives Used in the Stabilization of Expansive Soils, Geotechnical Testing Journal, 25 (2002), pp. 199-209.

[37] ASTM D 4318, Standard Test Methods For Liquid Limit, Plastic Limit, And Plasticity Index Of Soils, West Conshohocken, PA, USA, 2010.

[38] ASTM D 698, Standard Test Methods For Laboratory Compaction Characteristics Of Soil Using Standard Effort, West Conshohocken, PA, USA, 2012.

[39] ASTM D 559, Standard Test Methods for Wetting and Drying Compacted Soil-Cement Mixtures, West Conshohocken, PA, USA, 2015. 